УДК 811.133 .1

\title{
СТИЛІСТИЧНІ ОСОБЛИВОСТІ ГІПЕРТЕКСТОВИХ ПОСИЛАНЬ У ФРАНЦУЗЬКИХ ІНТЕРНЕТ-ЗМІ
}

\author{
КОВАЛЬОВА О. К. \\ кандидат філологічних наук, доцент \\ Дніпровський національний університет ім. Олеся Гончара \\ chelena2076@gmail.com
}

\begin{abstract}
Досліджено стилістичні особливості гіпертекстових посилань у французькій інтернет-газеті “20 minutes". Поняття гіпертекстового посилання витлумачено як комп'ютерний і водночас лінгвальний феномен. Гіперпосилання досліджено на трьох рівнях: лексичному, морфологічному та синтаксичному. Доведено, що гіпертекстові посилання інтернет-газети "20 minutes" $є$ цілісними, структурованими, функціонально важливими утвореннями, що взаємодіють з іншими елементами гіпертексту. Установлено, що їхня структура й особливості функціонування відображають поєднання стилістичних особливостей мови ЗМІ та мови Інтернету. 3'ясовано, що у творенні й застосуванні гіперпосилань автори спираються на комунікативні стратегії інформування, впливу та оцінки. Для цього вони обирають засоби, спрямовані на встановлення контакту з молодою аудиторією.
\end{abstract}

Ключові слова: гіпертекст, гіпертекстове посилання, інтернет-3МІ, стилістика.

\section{STYLISTIC FEATURES OF HYPERTEXT LINKS IN FRENCH INTERNET MASS MEDIA}

KOVALOVA Olena Kostiantynivna

Candidate of Philological Sciences, Associate Professor Oles Honchar Dnipro National University chelena2076@gmail.com

Introduction. The paper focuses on the stylistic features of hypertext links in French Internet newspaper " 20 minutes". The notion of a hypertext link is double faced: as a computer and as a linguistic phenomenon. The hypertext link is investigated at three levels: lexical, morphological and syntactic.

Purpose. The paper aims at finding out the hypertext links of Internet newspaper "20 minutes" and analyzing them as integral, structured, harmoniously existing units which interrelate with other elements of the hypertext. A combination of stylistic features of the language of mass media as well as the Internet can be observed in such a unit. The communicative strategies of informing, influencing and evaluating are effectively utilized so as to attract readers' attention. The means which are aimed at establishing contact with young audience are chosen for that purpose.

Methods. The research grounds on stylistic analysis, interpretative analysis, lexicosemantic analysis, and empiric method of classifying the results of investigation.

Results. At lexical level hyperlinks are characterized by widespread usage of the anglicisms, the prevalence of emotionally coloured, colloquial vocabulary and neologisms. At morphological level, numerous initial contractions and shortenings, combinations of the text with various significant images are intrinsic in hyperlinks. At syntactic level the hypertext links are peculiar for nominative, complex asyndetic sentences, isolation of attributes. The usage of elliptical constructions of various kinds has signs of the influence of the Internet language stylistics. Besides, irony takes a significant place among the means of figurative expression. The usage of irony imparts a shade of ironically critical evaluation, especially in the reports that relate to administrative officials and government institutions. 
Conclusions. The above-mentioned aspects of hyperlinks create the stylistic features of the language of the Internet. The paper concludes that derivation is considered to be a productive means of the formation of neologisms in the field of internet mass media. The utilization of irony, being a part of the traditional French political satire, helps to achieve the understanding between young generation of readers that is a characteristic feature of special outlook, predetermined by age peculiarities.

Keywords: hypertext, hypertext links, Internet mass media, stylistics, characteristic feature.

Формулювання проблеми та обгрунтування актуальності їі розв'язання. На сьогодні Інтернет вважають “символом доби інформаційного суспільства” (Кузнецова, 2014, с. 107). Електронні ЗМІ стали для сучасної людини одним з основних джерел отримання інформації. В умовах конкуренції на медіаринку набувають вирішального значення не так самі новини, як оперативність та спосіб їх подання. Змагаючись між собою, інтернет-видання відшукують актуальні стилістичні засоби приваблення читачів та максимально використовують можливості технології Web 2.0. Екстралінгвальні, або технологічні, фактори забезпечують такі базові ознаки інтернет-3МІ, як мультимедійність, інтерактивніть та гіпертекстуальність. Це дає підставу дослідникам констатувати "активізацію реципієнта до рівня повноправного автора" (Бичков, 2003), “розмиття межі між автором і читачем” (Артамонова, 2007, с. 6) та дійти висновку про те, що “Інтернет перетворив засоби масової інформації ... на засоби масової комунікації” (Артамонова, 2007, с. 5).

Гіпертекстуальність істотно розширює можливості інтернет-ЗМІ, адже порівняно 3 традиційними друкованими носіями нелінійна організація тексту дає читачеві змогу самому обирати послідовність ознайомлення з інформацією. Виходить, що кожен читач, активуючи серію гіперпосилань за власною логікою чи бажанням, щоразу формує новий варіант гіпертексту з індивідуальним змістом. У контексті взаємодії інтернет-видання з читачем гіперпосилання набувають визначальної ролі: від їхнього оформлення, змісту, прагматично-комунікативних настанов залежить, чи зацікавить читача інформація, яку вони пропонують.

Аналіз останніх досліджень і публікацій. Відомі численні визначення гіпертексту, що переконливо демонструють роботи сучасних дослідників (Дєдова, 2006; Калмиков, 2009; Стройков, 2009; Лутовінова, 2009; Соболєва, 2014; Попов, 2015; Лукіна, Фомичова, 2005). Більшість 3 названих дослідників уважає, що повноцінне функціонування гіпертексту можливе лише в кіберпросторі. Адже тільки в мережі гіпертекст набуває своїх принципових ознак: дисперсності, нелінійності, безкінечності, мультимедійності, інтерактивності. Роботи О. В. Дєдової (2006, 2008), Р. К. Потапової (2005), С. А. Стройкова (2009), С. О. Попова (2015), українського дослідника С. Г. Чемеркіна (2009) свідчать про ефективніть підходу, який поєднує два погляди на гіпертекст - як комп’ютерну технологію і як об’єкт лінгвістичного аналізу.

Є. О. Попов (2015) акцентує увагу на зв'язності та цілісності гіпертексту: “Гіпертекст це складне лінгвоінформаційне утворення, існування якого можливе переважно в кіберсередовищі, яке має навігаційний апарат, оформлений через гіперпосилання і “лінки” (як мовні, так і немовні), які актуалізують такі текстові категорії, як зв’язність та цілісність” (c. 171). О. В. Дєдова (2008) дає визначення гіпертексту, актуальне для інтернет-ЗМІ: “Модель організації електронного тексту, яка характеризується специфічною структурованістю і розгалуженою системою програмно підтримуваних внутрішньотекстових і міжтекстових переходів, яка передбачає можливість читацького інтерактивного впливу на послідовність відтворення композиційних одиниць” (с. 11).

Слід зазначити, що при популярності феномену гіпертексту серед сучасних спеціалістів, робіт, присвячених гіпертекстовим посиланням, значно менше. С. Л. Кушнерук (2007), Р. К. Потапова (2005), С. Г. Носовець (2001) пропонують класифікацію гіперпосилань, виходячи з формально-семантичних критеріїв. О. В. Дєдова (2008), А. Р. Утяшев (2015) досліждують 
формальні та семантичні аспекти функціонування гіпертексту в інтернет-ЗМІ. Українська дослідниця К. Іванова (2015) розглядає види та функції гіпертекстових зв'язків в інформаційноаналітичних інтернет-текстах. На думку Є. О. Попова (2015), феномен гіперпосилань досі недостатньо вивчений і потребує окремої уваги (с. 171). Зауваження цілком логічне, якщо врахувати, що гіперпосилання $\epsilon$ ключовим елементом гіпертексту, який забезпечує перехід від одного текстового рівня до іншого. С. Г. Чемеркін (2009) слушно відзначає зростання ролі гіперпосилань, їхню “комунікативну та стилістичну вагу” (с. 113).

Визначення гіпертекстового посилання, яке відображало б комп'ютерну й лінгвальну природу цього феномену, можливо, ще попереду. На сьогодні відомі кілька більш-менш узагальнювальних дефініцій. Є. О. Попов (2015) кваліфікує гіперпосилання як “навігаційний апарат гіпертексту” (с. 171). Схожим чином їх трактує Н. Смирнова (2017): “Засоби зв’язку вузлів, які задають потенційні можливості пересування по гіпертексту (навігації)” (с. 410). С. Г. Носовець (2011) уважає гіперпосилання “диференціальною ознакою гіпертексту, яка організує його структуру та забезпечує функціональність - навігацію” (с. 127). О. В. Дєдова (2008) визначає гіпертекстові посилання як двокомпонентний комплекс, що складається: 1) 3 джерела посилання - текстового або графічного зображення на екрані, через активацію якого викликається нове зображення; 2) з об'єкта (призначення) посилання, яким є нове зображення (текст, таблиця, малюнок і т. ін.).

У цій статті гіпертекстові посилання інтерпретуємо як структурно або графічно виділений елемент тексту, який є вихідною точкою гіпертекстового переходу і який семантично пов'язаний з об'єктом переходу.

Мета статті - виявити стилістичні особливості гіпертекстових посилань. Метеріалом дослідження обрано інтернет-газету “20 minutes”. Вибір саме цього видання зумовлений такими факторами: по-перше, за популярністю газета входить у першу трійку загальнонаціональних видань Франції; по-друге, вона адресована здебільшого молодій аудиторії, яка не читає традиційної друкованої преси. Досягнення мети передбачає розв'язання таких завдань: 1) розглянути особливості гіперпосилань на лексичному, морфологічному та синтаксичному рівнях; 2) з'ясувати, які засоби побудови гіпертекстових посилань використано для встановлення контакту з сучасними молодими читачами.

Виклад основного матеріалу. На рівні лексики в гіпертекстових посиланнях функціонують численні запозичення, насамперед англіцизми. Вони мають привабити читача, адже всупереч регуляторній політиці французької влади, спрямованій на обмеження надмірного вживання англізмів, молодь широко ними користується. У гіперпосиланнях наявні давновживані і звичні запозичення - parking, shopping, look, dress code, foot, rugby, basket, tennis, а також ті, що стали звичними в повсякденному мовленні молодих французів - fan, web, post, newsletter. До запозиченого іменника додається артикль: le post, le clash, le crash, les snipers.

Для назви однієї з рубрик ужито дієслово se coacher. Таку форму утворено від англійського дієслова coach за допомогою додавання закінчення -еr, яке вводить запозичене слово в дієслівну парадигму французької мови, та частку se, яка надає дієслову значення зворотності. Новоутворена лексема набуває значення “тренуватися, готуватися до чогось”. Відповідно рубрику присвячено рекомендаціям фахівців щодо правильної підготовки до занять спортом.

Щодо запозичень 3 інших мов, то в рубриці Jeux ужито назви інтелектуальних ігор японського походження - takuzu, sudoku, kakuro.

У “20 minutes”, на відміну від емоційно більш виважених текстів “Le Monde" або “Le Figaro", часто спостерігається емоційно забарвлена лексика. Ї̈̈ вживання покликане привернути увагу читача, апелювати до його цікавості або викликати інтерес до сенсацій, спонукати активувати гіперпосилання і прочитати повний текст повідомлення. Саме тому фіксуємо традиційні для мови преси епітети на кшталт tragique accident, terrible accident, images impressionantes, concert exeptionnel, folle histoire, video écoeurante. 
Більшість гіперпосилань (за винятком сервісних та рекламних) на головній сторінці інтернет-газети виступають своєрідними анонсами новинних повідомлень. Р. А. Утяшев (2015) у дисертаційній роботі, виконаній під керівництвом О. В. Дєдової, вдало називає такі гіперпосилання електронними хедлайнами. Він визначає хедлайн як “висловлювання новинного сайту, представлене у вигляді короткого новинного повідомлення, синтаксично самостійне, яке виконує роль джерела гіпертекстового переходу на сторінку з повним тектом повідомлення" (с. 76). Дослідник слушно зауважує, що хедлайн не тотожний із заголовком новинного тексту, оскільки заголовок разом з повним текстом новини розташовано на іншій інтернет-сторінці. Хедлайн $є$ “зовнішнім об’єктом щодо новинного тексту, тобто належить до іншого текстового простору "(Утяшев, 2015, с. 157). Загалом хедлайни виконують дві функціi: привернути увагу читача та інформувати його. А якщо врахувати просторову обмеженість для розміщення хедлайнів (суто технологічний фактор), то стає зрозумілим, що інформація має бути максимально сконцентрована. Відповідно спрощується синтаксична структура речень, які часто тяжіють до номінативних конструкцій, та помітно зростає їх змістове наповнення. Тут не може бути “зайвих” елементів, кожне слово має певне навантаження. Зазвичай хедлайни дають відповіді на ключові питання, які мають бути розкриті в повідомленні: хто? що? де? коли? Водночас уживання емоційно забарвленої лексики привертає увагу читача.

Для інтернет-видання “20 minutes” характерним є прийом неповного текстового збігу хедлайна із заголовком повідомлення. Хедлайн переважно більш емоційно забарвлений, ніж заголовок. "Les familles des victimes du vol MH17 furieux contre les journalistes" (24.12.2017). За допомогою номінативного речення увагу читача сфокусовано на актантах повідомлення хто (les familles des victimes du vol MH17), проти кого (contre les journalistes). Словосполучення le vol MH 17 стало для французьких медіа звичним скороченим позначенням рейсу літака, який було збито над територією України 17.04.14 р. У хедлайні вжито епітет furieux з високим ступенем негативного емоційного забарвлення, але не вказано причини розлюченості родин загиблих. Активувавши гіперпосилання, читач переходить на сторінку, де розташоване основне повідомлення. I бачить нейтрально забарвлений заголовок: "Vol MH17: Des proches des victimes dénoncent le traitement de restes humains découverts” (24.12.2017). Тобто, щоб привернути увагу читачів, у хедлайні ефективно використано прийом поєднання емоційності з неповним наданням інформації, інтригування читача.

Зафіксовані також приклади вживання в хедлайнах розмовної лексики. Її емоційна забарвленість вносить в анонс елемент оцінки подій: “Bazar dans les gares parisiennes, les voyageurs accusent la SNCF de surréservations” (23.12.2017). Іменник bazar, запозичений 3 тюркських мов, міцно ввійшов у повсякденний ужиток французів у його нейтральних значеннях: “критий ринок (у східних країнах)”, “універсальний магазин”. У розгляданому ж випадку це слово вжито з розмовним значенням “безлад”, “розгардіяш”, “колотнеча”. Негативний відтінок змісту підкреслено дієсловом accuser (звинувачувати). Як бачимо, цей хедлайн виконує потрійну функцію: повідомлення, привертання уваги й оцінки.

Наявність елементів розмовного регістру фахівці вважають однією з ознак сучасного публіцистичного стилю (Алєксєєв, 2010). Відхід від жорстких канонів 3 домінуванням нейтральної, офіційної суспільно-політичної лексики розглядається як ефективний спосіб привертання уваги молоді. Можна констатувати вживання розмовної, побутової, а іноді і зниженої лексики. Останнє можна проілюструвати за допомогою хедлайна "Bretagne: Sur le marché de Pontivy, le père Noël était une ordure" (19.12.2017). У тексті повідомлення йдеться про те, що напередодні Різдва чоловік у костюмі Діда Мороза грубо поводиться з дітьми і говорить їм огидні слова. У цьому контексті іменник иne ordure набуває вкрай негативного емоційного забарвлення, яке поєднується з оцінкою: сволота, гад, паскуда. Мета - здійснити вплив на читача, викликавши в нього огиду, зневагу, обурення поведінкою об'єкта повідомлення. 
На цьому і подібних прикладах можна помітити тенденцію сьогодення. 3 більшості ЗМІ читач отримує вже готову оцінку, йому не потрібно витрачати зусилля на формування власної. Наявність засобів, спрямованих на пропонування читачеві готових оцінок і суджень, спрощує та прискорює споживання інформації. В епоху цифрових технологій, коли вона поширюється у всі куточки планети майже миттєво, неймовірно зростає ії кількість. Відповідно зростає вага фактора оцінки: по-перше, оцінка спрощує сприйняття, по-друге, вона формує в аудиторії певні уявлення залежно від редакційної політики видання. Звичайно, вони стосуються не тільки окремо взятих випадків, а й серйозних глобальних проблем сьогодення. Це дає підставу деяким фахівцям висловлювати думку про те, що сучасний медіапростір все більше стає простором оцінок та суджень, а не простором інформації та іiї аналізу.

Інший приклад пов'язаний з використанням прямої мови як елемента гіперпосилання: “On s'emmerde au Parlement", estime le député Gilbert Collard" (22.12.2017). Дієслово s'emmerder (подихати від нудьги) відносять до розмовної та зниженої лексики. Привертання уваги реалізується наведенням саме цього висловлювання депутата, у якому вжито ненормативну лексику, адже іронічно-зневажливе ставлення до норми, канону, усталеності властиве частині молодого покоління. Орієнтованість масмедіа на конкретний тип читацької аудиторії зумовлює пошук мовленнєвих засобів, які б транслювали спільні з цією аудиторією ментальні та світоглядні коди. У цьому сенсі гіпертекстові посилання у вигляді хедлайнів $є$ одним 3 дієвих інструментів.

Можна констатувати інші численні вживання розмовної лексики: nanar (барахло, непотріб), une blague (жарт, байка, розіграш), moche (поганий, огидний, паскудний), une galère (складне становище, неприємність, прокол), un роте (приятель, кореш). В останньому випадку іменник un pote супроводжується незвичним написанням іменника fan: "7 cadeaux pour ton / ta pote faaaaaaaaaaan de Macron" (4.12.2017). Незвичне графічне оформлення, по-перше, привертає увагу своїм виглядом i, по-друге, іронічно підкреслює високий ступінь “фанства", тобто захопленості особистістю президента Французької Республіки. Присвійний прикметник створює ефект близького спілкування, скорочення дистанції між автором і читачем. Зауважимо, що un pote вжите автором лише в хедлайні, у заголовку ж використано нейтральний іменник un ami: "7 cadeaux pour ton ami faaaaaaaaaaan de Macron".

Традиційною для стилістики преси вважають велику кількість неологізмів (Морен, Тетеревникова, 1960, с.119; Алєксєєв, 2010, с. 143; Кузнецов, 2017, с. 88). Їх широке використання на сторінках газет сприяє поширенню і в суспільному середовищі, збагаченню та оновленню тим самим словникового складу мови. На думку В. Г. Кузнецова (2017), виникнення неологізмів “зумовлене факторами соціально-прагматичного характеру” (с. 88). До таких факторів він відносить екстралінгвальні - потребу в номінації нових предметів, явищ і внутрішньомовні тенденцію до уніфікації, системності мовних засобів (с. 89). Кожний період суспільного розвитку диктує появу власних неологізмів. У другій половині XX столяття до неологізмів відносили guerre froide, conférence au sommet, speakerine. Сучасні інтернет-газети використовують лексику епохи цифрових технологій. У гіпертекстових посиланнях бачимо іменники cybersécurité, cyberattaque, cyber-agresseur, утворені за допомогою префіксації. До форм sécurité, attaque, agresseur додано префікс cyber-, який має значення “той, що належить до сфери комп”ютерів та інтернету".

Продуктивним у сучасній французькій мові (як і в англійській) $є$ префікс $e$-, який також указує на належність конкретного поняття сфері комп'ютерних технологій. На головній сторінці сайту “20 minutes" фіксуємо іменники e-commerce, e-déclaration, e-constat. Неологізми утворені за допомогою суфікса -iste, продуктивність якого перевірена часом. Суфікс має значення “бути прибічником чогось або когось”. У минулому столітті преса широко вживала іменники на кшталт marxiste, socialiste. Зараз можна побачити djuhadiste (прибічник боротьби за мусульманську віру), macroniste (прибічник президента Макрона). Цікавим фактом $€$ те, що прізвище президента Макрона стало основою для утворення ще кількох неологізмів. У наступному хедлайні можна 
побачити таку форму: "Congrès LREM: Pourquoi Lyon est-elle la capitale de la "Macronie"? (22.01.2018). Додавання суфікса -іе до прізвищ керівників держави в різні періоди зумовлювало появу неологізмів Chiraquie, Hollandie, Sarcozie, а зараз - Macronie. Останній неологізм має іронічне забарвлення і означає частину території країни, яка $\epsilon$ осередком прибічників президента Макрона. Сучасним є також неологізм Macronleaks (або MacronLeaks), утворений поєднанням власної назви (у вигляді прізвища) та іменника leak, який в англійській мові має значення “витік інформації”. Це алюзія на відоме останніми роками поняття Wikileaks інтернет-сайт з документацією, яка розкриває приховані від широкого загалу деталі діяльності всесвітньо відомих політиків. За такою аналогією під назвою Macronleaks у мережі розміщено матеріали щодо роботи виборчого штабу тоді ще кандидата в президенти Макрона.

Численність і широта функціонування слів, утворених за допомогою афіксальної деривації, підтверджує думку сучасних фахівців про “зростаючу роль деривації в розвитку словникового складу та системи французької мови” (Алєксєєв, 2010, с. 108).

Екстралінгвальні фактори, пов'язані з виникненням нових реалій суспільно-політичного життя, дають поштовх утворенню семантичних неологізмів. Так, іменник la chancelière вживався в значенні “дружина канцлера". Після обрання Ангели Меркель канцлером Німеччини la chancelière набуває значення “жінка-канцлер”. Поширення неологізму réseaux sociàux спричинене виникненням соціальних мереж.

На лексичному рівні автори гіпертекстових посилань часто вживають англізми (і меншою мірою запозичення з інших мов), емоційно забарвлені епітети, лексику розмовно-побутового та зниженого стилю, неологізми. Слід зазначити, що поряд з цими засобами функціонує лексика, що традиційно становить ядро публіцистичного стилю, зокрема нейтральна суспільно-політична лексика, власні назви (топоніми, антропоніми, назви інституцій).

Однією $з$ характеристик мови Інтернету сучасний дослідник А. Овербек (A. Overbeck) уважає велику кількість різноманітних абревіатур (Овербек, 2014, с. 276), адже необхідність економії простору диктує економію мовних засобів. На морфологічному рівні гіпертекстовим посиланням властиве широке вживання ініціальних скорочень (sigles) і усічень (troncations). Зазвичай ініціальні скорочення гіперпосилань є загальновживаними: SNCF (Société Nationale de Chemins de Fer), NY (New York), SMIC (Salaire minimum interprofessionnel de croissance), SDF (Sans domicile fixe) і т. ін. $€$ новостворені абревіатури, такі, як LREM з варіантами LaREM, REM, LRM (La République en marche), що називають політичну партію, створену президентом Макроном у 2016 p.

Властиві для мови Інтернету також поєднання слів зі знаками. Посилання $+d$ 'articles пропонує більше найактуальніших статей. Знак + замінює прислівник plus для економії простору та привертання уваги. За таким же принципом побудовано гіперпосилання les +lus (читають), les +commentüs (коментують), les + partagŭs (діляться).

Поширені також усічення, властиві мові ЗМІ, мові Інтернету, розмовній мові. Здебільшого це апокопи: info, déco, ado, foot, actu, kiné, manif, récap' (récapitulatif).

Отже, на рівні морфології ініціальні скорочення, поєднання слів зі знаками, усічення виступають продуктивними засобами економії простору та привернення уваги. Уживання часових форм лишається достатньо стабільним і традиційним для мови преси в їі класичному варіанті. Актуальність змісту виражається вибором часів, значення яких фіксує зв'язок 3 теперішністю: présent, futur proche, futur simple, passé composé, пасивні форми названих часів. Іноді можна бачити conditionnel présent у повідомленнях, достовірність яких є сумнівною.

Синтаксична побудова гіперпосилань зумовлена їх специфікою як елементів, що скеровують читача до необхідної інформації. Семантичним ядром скерування може виступати окреме слово, наприклад назва рубрики інтернет-газети (politique, société, monde etc.). Внутрішньотекстовим посиланням може бути і слово, і словосполучення або частина речення, залежно від семантичного зв'язку посилання з текстом повідомлення. 
Для нашого дослідження становлять інтерес саме речення з потужними виражальними можливостями. Їх уживання зумовлене трьома основними тенденціями мови інтернет-3МІ: привернути увагу, передати всі інформаційно значущі компоненти й зробити це лаконічно. Дуже зручними в цьому сенсі є розповідні номінативні речення. "Trois échouages de dauphins en moins de 24 heures dans le Var" (26.01.2018). "Intronisation médiatique ce jeudi soir pour Laurent Wauquiez" (25.01.2018). "Carles Puigdemont officiellement candidat à la présidence de la région" (22.10.2018).

Уживаються також складні безсполучникові речення: “ Ukraine: Un dépôt de munitions en feu, 30.000 personnes évacuées” (27.09.2017). Такий тип речень імітує телеграфний стиль заголовків класичної друкованої преси. Поширений він і в мові інтернет-ЗМІ. Інформацію передано максимально концентровано: читач одразу дізнається, що саме трапилося, де, з якими наслідками. Вираз en feu надає повідомленню яскравої образності, числівник створює сенсаційний характер повідомлення. Часто складні безсполучникові речення використовують для повідомлення про катастрофи, катаклізми, стихійні лиха та інші подібні події. Прості речення як компоненти складних безсполучникових речень можуть бути односкладними номінативними (як у попередньому прикладі) і двоскладними. “Un bus fonce dans la foule à Moscou, la thèse de l'accident est privilégiée" (25.12.2017).

Речення $з$ порушенням традиційного порядку слів неодмінно привертають увагу. До таких речень належать хедлайни з відокремленими означеннями: “Critiquée, la chanteuse Lorde annule un concert à Tel-Aviv” (25.12.2017). У початкову позицію винесено головний компонент повідомлення - дієприкметник critiquée. У цій позиції він указує на причину події, про яку йдеться в наступній частині речення: співачка скасувала виступ через критику на свою адресу. Поширені також відокремлені обставини, зокрема обставини місця: “Coincé dans la cheminée, le cambrioleur est obligé d'appeler la police" (18.12.2017).

Спеціалісти констатують зближення публіцистичного стилю 3 розмовним не тільки на лексичному, а й на синтаксичному рівні (Кузнецов, 2017, с. 104). В інтернет-пресі ця тенденція набирає обертів. Одна 3 рубрик має назву: “Т’as vu?” Усічення займенника є типовим для розмовної мови. 3 метою мовної економії використано еліпсис: "Djokovic pas sûr de reprendre à l'Open d'Australie” (29.12.2017). Опущення дієслова разом із заперечним прислівником також притаманне розмовній мові. Як різновид еліпсису в хедлайнах функціонує паратаксис, за якого видаленню підлягає артикль або прийменник. Яскравим прикладом паратаксису є такий хедлайн: "Quand les Stentors parlent cadeaux moches, espace et chaussettes" (23.12.2017).

Отже, синтаксису гіпертекстових посилань властиві односкладні номінативні або двоскладні речення, імітація телеграфного стилю за допомогою складних безсполучникових речень, відокремлення означень, використання різноманітних еліптичних конструкцій, що наближає стиль гіперпосилань до розмовного.

Для встановлення емоційного контакту з читачем, для залучення його до кола постійних відвідувачів автори гіперпосилань застосовують засоби образної виразності - метонімію, метафору й особливо іронію. Метонімія має достатньо традиційний характер, як-от: "Рaris et Berlin appellent au respect du cessez-le-feu en Ukraine” (28.08.2017). За принципом метонімії вжито іменник Internet, який міцно входить у повсякденний обіг: “Internet mobilisé pour retrouver un chien guide d'aveugle disparu” (29.12.2017). Іменником Internet позначено користувачів усесвітньої мережі. Метонімічне перенесення, яке надає неістоті певних ознак істоти, наявне також у гіперпосиланні “Qui sont les plus grosses fortunes mondiales?” (28.12.2017). Іменником fortunes названо людей, які володіють найбільшими статками.

Уживання метафоричних образів притаманне гіпертекстовим посиланням меншою мірою. Метафори не є поширеними, крім того, вони належать до так званих метафор зі стертою образністю, як, наприклад, “vague de froid”. Зрідка трапляються яскраві метафори, як-от: 
"Comment Emmanuel Macron veut dépoussiérer le rituel des vœux présidentiels" (28.12.2017). У словосполученні dépoussiérer le rituel дієслово має переносне значення - "оновити, освіжити". Його образність пов'язана зі значенням “вибити пил”, тобто змінити щось застаріле, настільки давне, що вкрилося пилом. Пил утілює образ чогось незмінного, чого ніхто не торкався довгий час і тому воно може стати взагалі непотрібним. У виборі саме дієслова dépoussiérer (а не нейтрального changer, наприклад) відчутне іронічне ставлення автора цього гіперпосилання до узвичаєної традиції президентського вітання з Новим роком.

Іронія створюється й кількома іншими засобами, наприклад, за допомогою антитези. “Gares bondées, trains surchargés... Mais rien d'anormal, selon la SNCF ” (24.12.2017). Іронічний ефект виникає 3 протиставлення реального стану справ - переповнених вокзалів та потягів i твердження перевізника, згідно з яким, усе гаразд. Водночас до іронії додається негативно забарвлений емоційний відтінок. При прочитанні тексту повідомлення за другою частиною речення відкривається засудження небажання транспортної компанії визнати складність ситуації і той факт, що вона недостатньо оперативно та ефективно реагує на проблему.

Іронія реалізується завдяки грі слів: “Les drôles de comptes du ministre des Comptes publics, Gérald Darmanin” (20.12.2017). Автор гіперпосилання натякає на дивне походження банківських рахунків (comptes) міністра бюджету та державних рахунків (Comptes publics) - посадової особи, статки якої мають бути вдвічі більш прозорими від інших посадовців, оскільки їй довірено управління рахунками держави. Зауважимо, що іронічного ефекту досягнуто також еліптичною формою ministre des Comptes publics, адже повна назва відповідного міністерства - Ministère de l'Action et des Comptes publics.

Іронія може бути реалізована через алюзію, як, наприклад, у хедлайні: “Trump or not trump ces phrases?” (20.01.2018). Інтертекстуальна алюзія, у цьому випадку іiі різновид - інтерполяція, відсилає до шекспірівського “То be or not to be?". Дієслово trump обрано як суголосне з прізвищем американського президента - особи, на яку сучасна преса звертає багато уваги не тільки 3 політичних міркувань, а й великою мірою через його епатажні вчинки та висловлювання. Хедлайн може бути перекладено як “Перевершити або не перевершити?". Активувавши його, читач бачить заголовок: “Un an de Trump à la Maison Blanche : Saurez-vous reconnaitre ses punchlines?”. Основний текст статті наводить найбільш резонансні та провокативні висловлювання Дональда Трампа, які були в центрі медійної уваги протягом року. Іронія полягає в тому, що наприкінці статті автор повідомляє, що у французькій політиці $є$ не менш “здібні” особи, здатні скласти Трампові конкуренцію на полі епатажності. Чи зможуть вони перевершити Трампа - це справа часу, іронічно зауважує автор.

Висновки й перспективи подальших досліджень. Отже, гіпертекстові посилання інтернетгазети “20 minutes" $є$ цілісними, структурованими, функціонально важливими компонентами, що взаємодіють з іншими елементами гіпертексту. Гіпертекстові посилання поєднують стилістичні особливості мови ЗМІ та мови Інтернету. Вони реалізують актуальні комунікативні стратегії інформування, впливу й оцінки.

На лексичному рівні специфіка гіперпосилань виявляється в широкому уживанні англізмів, емоційно забарвленої, просторічно-розмовної лексики та неологізмів. Для утворення неологізмів здебільшого використовують афіксацію.

На рівні морфології знаковими для гіперпосилань $є$ численні ініціальні скорочення та усічення, поєднання тексту зі знаковими зображеннями. Ці особливості гіперпосилань відповідають стилістиці мови Інтернету.

На синтаксичному рівні гіпертекстовим посиланням властиві односкладні номінативні, складні безсполучникові речення, відокремлення означень.

Серед засобів образної виразності домінує іронія, що надає відтінку іронічно-критичної оцінки, особливо в повідомленнях, які стосуються посадових осіб та державних установ. 
Застосування іронії, як частини традиції французької політичної сатири, має на меті знаходження спільної мови з молодим поколінням читачів, якому внаслідок вікових особливостей притаманний саме такий світогляд.

Гіпертекстові посилання є самостійним феноменом, який потребує подальшої уваги дослідників. Дефініція гіперпосилання як одночасно лінгвального і комп’ютерного явища, критерії можливих класифікацій гіперпосилань, їхні прагматичні та когнітивні особливості напрямки, які видаються перспективними для майбутніх розвідок.

\section{ЛІТЕРАТУРА}

Артамонова, I. М. (2007). Інтернет як специфічний тип мас-медійного тексту (на матеріалах українського сектору мережі). Вісник СумДУ. Серія Філологія, 2, 5-9.

Алєксєєв, А. Я. (2010). Нариси з контрастивної стилістики франиузької мови. (Навчальний посібник для факультетів іноземних мов університетів). Вінниця: Нова книга.

Бычков, В. В. Гипертекст. Лексикон нонклассики. Художественно-эстетическая культура XX века. Взято $3 \mathrm{https} / / /$ dic.academic.ru/dic.nsf/enc_culture/

Дедова, О. В. (2006). Лингвосемиотический анализ электронного гипертекста (на материале русскоязычного интернета). (Автореферат дис. докт. филол. наук). Москва.

Дедова, О. В. (2008). Теория гипертекста и гипертекстовые практики в Рунете. Москва: МАКС Пресс.

Иванова, К. (2015). Функции гипертекстовых связей в информационно-аналитических интернеттекстах. Cuadernos de Rushstica Espacola, 11, 53-60.

Калмыков, А. А. (2009). Интерактивная гипертекстовая журналистика в системе отечественных СМИ. Москва: Академия медиаиндустрии.

Кузнецов, В. Г. (2017). Функциональные стили современного франиузского языка: Публицистический и научный: Москва: Книжный дом “Либроком”.

Кузнецова, М. О. (2014). Гіпертекстуальність як іманентна характеристика вторинного дискурсу англомовних текстів сучасної маскультури. Нова філологія, 66, 107-110.

Кушнерук, С. Л. (2007). Расширение коммуникативного пространства: специфика текстов электронных СМИ в сравнении с печатными. Политическая лингвистика, 3(23), 140-143.

Лукина, М. М., Фомичева, И. Д. (2005). СМИ в пространстве интернета . Москва: Факультет журналистики МГУ.

Лутовинова, О. В.(2009). Гипертекст: понятие, основные характеристики, возможные подходы к лингвистическому анализу. Известия Волгоградского государственного педагогического университета. Взято з https://cyberleninka.ru/article/n/gipertekst-ponyatie-osnovnye-harakteristikivozmozhnye-podhody-k-lingvisticheskomu-analizu

Морен, М. К. и Тетеревникова, Н. Н. (1960). Стилистика современного франиузского языка. Москва: Издательство литературы на иностранных языках.

Носовец, С. Г. (2011). Гипертекстовые ссылки в интернет-СМИ: опыт типологической характеристики. Вестник Челябинского государственного университета. Филология. Искусствоведение, 17(232), 127-131.

Попов, Е. А. (2015). Подходы к изучению гипертекста. Вестник Ленинградского государственного

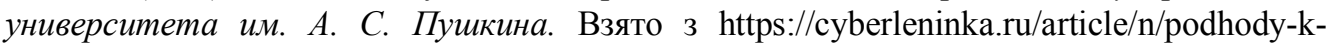
izucheniyu-giperteksta

Потапова, Р. К. (2005). Новые информационные технологии и лингвистика. Москва: КомКнига.

Соболева, О. В. (2014). К проблеме определения понятия “гипертекстуальность”. Вестник Челябинского государственного университета. Филология. Искусствоведение, 7(336), 72-75.

Смирнова, Н. Стилистические особенности представления события в интернет-СМИ. Взято 3 http://elib.bsu.by/bitstream/123456789/168958/1/408-414.pdf 
Стройков, С. А. Изучение гипертекста и гипертекстуальности в контексте современной лингвистики. Взято з https://cyberleninka.ru/article/n/izuchenie-giperteksta-i-gipertekstualnostiv-kontekste-sovremennoy-lingvistiki

Утяшев, А. Р. (2015). Формальные и семантические аспекты гипертекстуальности новостных сообщений в Рунете. (Дис. канд. филол. наук). Москва.

Чемеркін, С. Г. (2009). Репрезентативність гіпертексту у функціонально-стильових різновидах української мови в Інтернеті. Актуальні проблеми української лінгвістики: теорія і практика, $19,111-116$.

Overbeck, Anja. (2015). La communication dans les médias électroniques. Manuel de linguistique française. (P. 275-292). Berlin/Boston: Claudia Polzin-Haumann et Wolfgang Schweickard.

\section{REFERENCES}

Artamonova, I. M. (2007). Internet yak spetsyfichnyy typ mas-mediynoho tekstu (na materialakh ukrayinskoho sektoru merezhi). Visnyk SumDU. Seriya Filolohiya,2, 5-9.

Alyeksyeyev, A. Ya. (2010). Narysy z kontrastyvnoyi stylistyky frantsuz'koyi movy. (Navchal'nyy posibnyk dlya fakul 'tetiv inozemnykh mov universytetiv). Vinnytsya: Nova knyha.

Bychkov, V.V. Gipertekst. Leksikon nonklassiki. Khudozhestvenno-esteticheskaya kul'tura XX veka. Vzyato z https://dic.academic.ru/dic.nsf/enc_culture/

Dedova, O. V. (2006). Lingvosemioticheskiy analiz elektronnogo giperteksta (na materiale russkoyazychnogo interneta). (Avtoreferat dis. dokt. filol. nauk). Moskva.

Dedova, O. V. (2008). Teoriya giperteksta i gipertekstovyye praktiki v Runete. Moskva: MAKS Press.

Ivanova, K. (2015). Funktsii gipertekstovykh svyazey v informatsionno-analiticheskikh internet-tekstakh. Cuadernos de Rushstica Espacola, 11, 53-60.

Kalmykov, A. A. (2009). Interaktivnaya gipertekstovaya zhurnalistika v sisteme otechestvennykh SMI. Moskva: Akademiya mediaindustrii.

Kuznetsov, V. G. (2017). Funktsional'nyye stili sovremennogo frantsuzskogo yazyka: Publitsisticheskiy i nauchnyy. Moskva: Knizhnyy dom "Librokom".

Kuznetsova, M. O. (2014). Hipertekstual?nist? yak imanentna kharakterystyka vtorynnoho dyskursu anhlomovnykh tekstiv suchasnoyi maskul?tury. Nova filolohiya, 66, 107-110.

Kushneruk, S. L. (2007). Rasshireniye kommunikativnogo prostranstva: spetsifika tekstov elektronnykh SMI v sravnenii s pechatnymi. Politicheskaya lingvistika, 3(23), 140-143.

Lukina, M. M., Fomicheva, I. D. (2005). SMI v prostranstve interneta. Moskva: Fakul'tet zhurnalistiki MGU.

Lutovinova, O. V.(2009). Gipertekst: ponyatiye, osnovnyye kharakteristiki, vozmozhnyye podkhody $\mathrm{k}$ lingvisticheskomu analizu. Izvestiya Volgogradskogo gosudarstvennogo pedagogicheskogo universiteta. Vzyato z https://cyberleninka.ru/article/n/gipertekst-ponyatie-osnovnye-harakteristikivozmozhnye-podhody-k-lingvisticheskomu-analizu

Moren, M. K. i Teterevnikova, N. N. (1960). Stilistika sovremennogo frantsuzskogo yazyka. Moskva: Izdatel'stvo literatury na inostrannykh yazykakh.

Nosovets, S. G. (2011). Gipertekstovyye ssylki v internet-SMI: opyt tipologicheskoy kharakteristiki. Vestnik Chelyabinskogo gosudarstvennogo universiteta. Filologiya. Iskusstvovedeniye, 17(232), 127-131.

Popov, Ye. A. (2015). Podkhody k izucheniyu giperteksta. Vestnik Leningradskogo gosudarstvennogo universiteta im. A. S. Pushkina. Vzyato z https://cyberleninka.ru/article/n/podhody-k-izucheniyugiperteksta

Potapova, R. K. (2005). Novyye informatsionnyye tekhnologii i lingvistika. Moskva: KomKniga.

Soboleva, O. V. (2014). K probleme opredeleniya ponyatiya "gipertekstual'nost"'. Vestnik Chelyabinskogo gosudarstvennogo universiteta. Filologiya. Iskusstvovedeniye, 7(336), 72-75. 
Smirnova, N. Stilisticheskiye osobennosti predstavleniya sobytiya $v$ internet-SMI. Vzyato $\mathrm{z}$ http://elib.bsu.by/bitstream/123456789/168958/1/408-414.pdf

Stroykov, S. A. Izucheniye giperteksta i gipertekstual'nosti v kontekste sovremennoy lingvistiki. Vzyato z https://cyberleninka.ru/article/n/izuchenie-giperteksta-i-gipertekstualnosti-v-kontekstesovremennoy-lingvistiki

Utyashev, A. R. (2015). Formal'nyye i semanticheskiye aspekty gipertekstual'nosti novostnykh soobshcheniy v Runete. (Dis. kand. filol. nauk). Moskva.

Chemerkin, S. H. (2009). Reprezentatyvnist? hipertekstu u funktsional?no-styl?ovykh riznovydakh ukrayins'koyi movy v Interneti. Aktual?ni problemy ukrayins?koyi linhvistyky: teoriya i praktyka, 19, 111-116.

Overbeck, Anja. (2015). La communication dans les mŭdias ŭlectroniques. Manuel de linguistique franzaise. (P. 275-292). Berlin/Boston: Claudia Polzin-Haumann et Wolfgang Schweickard .

Дата надходження до редакиії 12.03.2018 р.

Ухвалено до друку 27.04.2018 p. 